\title{
Exemption of the responsibility of the medical doctor for medical practice: Assistant medical doctor example
}

\author{
Hekimin hukuki sorumluluğunun istisnaları: Asistan hekim örneği
}

\author{
Emine Meliknur Kılıç (D) \\ Istanbul Bilgi University, Graduate Programs Institute, Istanbul, Turkey
}

\begin{abstract}
Objective: In this study, the legal responsibility of the physician was evaluated within the framework of Turkish Law on the basis of the sample of the limits of the liability caused by the medical practice errors performed by the assistant physicians who received specialist training in medicine or dentistry. Materials and methods: Within the scope of "the circular of B.10.0.SHG.0.18.00.00-252.99 dated 28/09/2012, the General Directorate of Health Services of the Ministry of Health of the Republic of Turkey", the acts performed by the resident physician and the structure of the responsibility arising due to these are interpreted and evaluated together with the provisions of Turkish Law legislation and administrative procedures. In this context, the responsibility of the teaching assistant, chief assistant and specialist physician who supervised the assistant physician was evaluated.

Results: There is no direct regulation on the responsibility of the physician in the Turkish legal system. The treatment contract, which is a mixed atypical contract, is applied directly or comparatively with the provisions of various legislation, especially the Turkish Code of Obligations. As an exception to the responsibility of the physician, the relationship of responsibility established with the circular, between the assistant physician and the supervising physician in terms of private law may be based on the provisions of Articles 66 and 507 of the Turkish Code of Obligations. Turkish Criminal Law regulates the limits of responsibility in the context of the principle of the personality of crime and punishment.

Conclusion: From a criminal point of view, due to the principle of the personality of crime and sentence, the assistant physician is directly responsible, while the supervising physician is responsible for the offense of abuse of office due to a breach of the obligation of supervision and care. From a legal point of view, it is possible to talk about the responsibility of the supervising physician in accordance with the provisions of the obligation of care that the man employee and the attorney should show to the third party. It is possible that the supervising physician can be relieved of the responsibility by proving that the obligation of care and supervision has been fulfilled in recourse lawsuits or compensation lawsuits filed due to medical malpractice. Keywords: Assistant medical doctor, chief assistant, civil law, criminal law, malpractice, responsibility, specialist medical doctor.
\end{abstract}

\section{öz}

Amaç: Bu çalışmada hekimin hukuki sorumluluğu, tıpta yahut diş hekimliğinde uzmanlık eğitimi alan asistan hekimlerin gerçekleştirdikleri tıbbi uygulama hataları nedeniyle meydana gelen sorumluluğun sınırları örneklemi esas alınarak Türk Hukuku çerçevesinde değerlendirilmiştir.

Gereç ve yöntemler: "TC. Sağlık Bakanlığı Sağlık Hizmetleri Genel Müdürlüğü 28/09/2012 tarih ve B.10.0.SHG.0.18.00.00-252.99- sayılı genelgesi”" kapsamında asistan hekimin gerçekleştirdiği fiiller ve bunlar nedeniyle meydana gelen sorumluluğun yapısı Türk Hukuk mevzuatı hükümleri ve idari işlemler birlikte değerlendirilerek yorumlanmıştır. Bu bağlamda asistan hekimi gözeten eğitim görevlisi, başasistan ve uzman hekimin sorumluluğu değerlendirilmiştir.

Bulgular: Türk Hukuk sisteminde hekimin sorumluluğuna ilişkin doğrudan bir düzenleme bulunmamaktadır. Karma nitelikli atipik bir sözleșme olan tedavi sözleşmesine başta Türk Borçlar Kanunu olmak üzere çeşitli mevzuatlardaki hükümler doğrudan veya kıyasen uygulanmaktadır. Hekim sorumluluğunun bir istisnası mahiyetinde olarak genelge ile idari açıdan asistan hekim ile gözeten hekim arasında kurulan sorumluluk ilişkisi özel hukuk bağlamında Türk Borçlar Kanununun 66. ve 507. madde hükümleri temeline dayandırılabilir. Türk Ceza Hukuku ise suç ve cezanın şahsiliği ilkesi bağlamında sorumluluğun sınırlarını düzenlemektedir.

Sonuç: Cezai açıdan suç ve cezanın şahsiliği ilkesi nedeniyle asistan hekim doğrudan sorumlu iken nezaret eden hekim gözetim ve özen yükümlülüğünün ihlali nedeniyle görevi kötüye kullanma suçu ile sorumludur. Hukuki açıdan ise adam çalıştıranın ve vekilin işi üçüncü kişiye gördürmesinde göstermesi gereken özen yükümlülüğü hükümleri doğrultusunda kıyasla nezaret eden hekimin sorumluluğundan söz etmek mümkündür. İdarenin rücu davalarında yahut tıbbi uygulama hatası nedeniyle açılan tazminat davalarında, nezaret eden hekimin özen ve gözetim yükümlülüğünün yerine getirildiğinin ispatı ile sorumluluktan kurtulması mümkündür.

Anahtar sözcükler: Asistan hekim, özel hukuk, ceza hukuku, malpraktis, sorumluluk, uzman hekim, başasistan.

Received: May 28, 2019 Accepted: November 21, 2019 Published online: March 16, 2020

Correspondence: Emine Meliknur Kılıç. Cebeci \& Cebeci Avukatlık Ofisi , Mansuroğlu Mah. 288/1 Sok. İzmir Sitesi, No: 6/7, Bayraklı, İzmir, Turkey. Tel: +90 232 - 4610555 e-mail: av.eminemeliknur@gmail.com 
Legal responsibility of doctors has not been specifically regulated in the Turkish legal system. While the relevant provisions of the Turkish Penal Code No. 5237 (TCK) published in the Official Gazette No 25611 dated 12/10/2004 for the criminal responsibility arising from the actions they commit due to their professions are subject to the permission of the local authority or directly applied, in terms of its legal responsibilities, the general provisions of the Law No. 6098 of the Turkish Code of Obligations (TBK), published in Official Gazette No. 27836 dated 4/02/2011 and the special provisions of the concrete case are applied together in terms of the specific structure of the medical contract. The administrative responsibility of the physician may also occur due to the application error, but this issue is not the focus of our article.

Any act which is deemed to be a crime and unjust act against the integrity of the body by any person is in accordance with the law when the physician has carried out it in accordance with the Medical Deontology Regulation published in the Official Gazette No. 10436 dated 19/02/1960 and it has the conditions for medical intervention. However, physicians have compensation liability for damages during medical practice and criminal liability to the extent of the error. ${ }^{[1]}$

\section{Resident physicians}

A resident physician is defined as a specialist student in Article 3/1 of the Regulation on Specialist Training in Medicine and Dentistry Regulation published in the Official Gazette dated 26/04/2014 and numbered 28983 issued by the Ministry of Health. According to this definition, the person undergoing specialist training in medicine or dentistry is a specialist, regardless of the staff and position in the institution where he/she has been placed based on ÖSYM exam results by graduating from the related faculty (medicine/dentistry) in order to gain the right to apply his art and use the title of expertise in that branch. This training is given in state or foundation university medical faculty hospitals or research and training hospitals of health science universities. The public nature and subordination to administrative law of research and training hospitals and state university medical faculty hospitals is undisputed. On the other hand, foundation universities are subject to administrative law due to the establishment of law and providing public services based on this law. This matter is decided by the General Assembly of the Supreme Court of Appeals (HGK) 2012/4-729 Decision, 2013/163, dated 30/01/2013 as follows, "A foundation university's faculty of medicine hospital is a public hospital in terms of the health service it provides to the public, and the defendant employee is a public official. Although the action is based on carelessness and imprudence, the action occurred during service, is related to the service, and is a defect of service in nature, animosity in the present case falls on the administration, not the public official. The case should be filed against the administration and hostility should be directed towards administration". ${ }^{[2] *}$

According to Regulation on Graduate Education and Training published in Official Gazette No. 29690 dated 20/04/2016 Article 16/2** and provision of $16 / 1-b$, a person who graduated from medical school graduates with a master's degree. For this reason, although the specialty education in medicine or dentistry is perceived as a PhD degree, this notion is not supported at an international level. On the other hand, medical faculty graduates enrolled in doctorate programs $(\mathrm{PhD})$ opened by basic medical science departments of university medical faculties cannot use the title of resident doctor or specialist student. According to the Higher Education Law No. 2547 published in the Official Gazette dated 06/11/1981 and numbered 17506, those who are employed in this program use the title and authority of research assistant, but they cannot actively practice the profession of medicine within the scope of the university.

Therefore, after specialist training, resident doctors obtain a license, which is not equivalent to a $\mathrm{PhD}$, to treat patients in that area of expertise within the borders of Turkey. During their specialty training, due to their lack of licenses in that field, they can participate in the patient examination and treatment process under the supervision and responsibility of a specialist physician within the "framework of the authority and responsibilities of a general practitioner". 


\section{MATERIALS AND METHOD}

\section{Responsibility of the Supervising Specialist Physician for the Errors of Medical Malpractice by the Resident Physician}

\section{Definition of medical malpractice and physician responsibility in general}

Medical practice constitutes of all forms of interventions directed by the physician towards the patient in accordance with medical science and ethics aiming to diagnose and treat or prevent bodily, physical, or mental illness. ${ }^{[3]}$ More broadly and comprehensively, medical practice is defined as "all forms of activities, ranging from the simplest diagnostic and treatment methods to the most severe surgical interventions, for the diagnosis and treatment of bodily, physical, mental illness; alleviation or relieving of pain when this is not possible; and prevention of these illnesses, carried out in accordance with the principles generally accepted by the medical science by persons authorized by law to perform the medical profession for the purpose of population planning". ${ }^{[4]}$

The physician is under the obligation of knowledge, experience, attention, and care, and is liable for even slight negligence during medical practice, however, complications are excluded. The prioritized conditions in terms of legality in medical practice is as follows: being a physician or a healthcare professional under the supervision of a physician, consent of the informed patient, and indication (medical necessity). ${ }^{[5]}$ If these conditions are not cumulatively involved in the concrete event, the act of intentional injury occurs.

Medical practice error (malpractice) occurs in event of violation of the liability borne by the medical contract during medical practice and appropriate causation by the physician, except in case of complications. Malpractice was defined by the World Medical Association at the $44^{\text {th }}$ General Assembly held in 1992 as "the physician's failure to conform to the standard of care for treatment of the patient's condition, or a lack of skill, or negligence in providing care to the patient, which is the direct cause of an injury to the patient". ${ }^{[6]}$

On the other hand, the means by which resident physicians will receive training during the specialist training and participation in the examination process is regulated by the Regulation. Furthermore, published by the Turkish Medical Association in March 2015, the declaration, "Resident Physicians Have Rights! We Demand Qualified Specialist Training!" described educators participating in the specialty training process as "Patient care is the best training", contrary to what it should be. ${ }^{[7]}$

In fact, the Circular No. B.10.0.SHG.0.18.00.00-252.99 dated 28/09/2012 of the Turkish Ministry of Health General Directorate of Health Services has granted permission to resident physicians who do not possess expert knowledge and skills to participate in the medical practice process under the supervision of an educator, chief resident, or specialist. In addition, it was emphasized that the supervising educator, chief resident, or specialist would be held responsible for the medical practice, planned treatment, and possible practice errors carried out by the resident physician. While the Ministry of Health holds the supervisor of the resident physician liable for the medical malpractice that would occur, the type or scope of this liability was not disclosed. However, according to Article 13 of the Administrative Procedure Law No. 2577 published in the No. 17580 Official Gazette dated $20 / 1 / 1982$, the person who has suffered due to medical malpractice in any case must apply to the relevant administration for compensation for the damage caused by the service administration within one year and in any case within five years after learning of the offending action or action resulting from the harm.

\section{RESULTS}

\section{Criminal liability}

Undoubtedly, the relevant educator, chief resident or specialist physician supervising the resident physician cannot be held directly liable in criminal terms for the perpetration of the act due to medical errors. In accordance with the TCK Article $20^{* * *}$ which regulates the principle of the privity of crime and punishment "privity of criminal liability", the supervisor cannot be held directly liable for the medical malpractice, regardless of the degree of violation by the resident physician. However, it is possible to mention the rate of defect caused by the supervisor's negligence. As long as a link can be established between the act and the perpetrator, which does not interrupt the 
causal link, the supervisor is subject to the TCK Article 257 titled "misconduct of duty".

If the causal relationship is interrupted by the third person (resident physician, patient, etc.), the criminal liability of the supervising physician may be removed or the measure of defect may be reduced. Although not limiting in nature, if the act is outside of the supervisor's reign of authorization, or if the patient or resident physician takes the risk upon themselves, criminal liability of the supervisor is out of the question.

\section{Legal responsibility}

Unlike criminal liability, it is possible to mention the supervising physician's legal responsibility of the resident physician. According to the Ministry of Health's circular dated 28/09/2012, it was stated, "It is useful to remind the patients that the supervising educator, chief resident, or specialist is responsible for applications and planned treatments" in which the supervising physician is held responsible for the action along with the resident physician. Similar to the responsibility of the employee in terms of debt relations, comparative to the provision of TBK Article 66, the aforementioned Circular forms joint presumption of liability between the resident physician and responsible supervisor within scope of TBK Article 61. Under Article 66, the legislator sought the conditions of "inspection, supervision and employment under orders/ instructions". The circular's statement of "All applications and treatments requiring expertise knowledge and skills must be carried out under specialist supervision and responsibility and strictly followed up by the relevant institutional managers and educational supervisors to ensure that it is carried out correctly" puts forth supervision and inspection responsibility as well as instruction during treatment procedure, similar to employer responsibility of Article 66. Therefore, the presumption of joint liability prescribed by the circular is comparatively based on the terms of the Turkish Code of Obligations.

A resident physician who is a graduate of medical school is responsible for his/her actions as a general practitioner. In addition to theoretical education during the residency training, the students gain expertise and knowledge through practical studies on the model. The supervising physician, who is liable for duty of care, will be relieved of the responsibility by proving that the resident physician possesses sufficient knowledge and skills within the framework of the trainings provided, by assigning of a resident who can perform the medical intervention properly, and has fulfilled their obligation of supervision and inspection. While burden of proof belongs to the supervising physician, TBK Article 66 is applied comparatively to determine the degree of responsibility.

As far as the chain of responsibility is concerned, the resident and/or supervising physician performing the medical practice are not directly responsible for the damage that occurs. As explained earlier, specialized training is provided in state and foundation universities hospitals and training and research Hospitals subject to administrative law. In any case of injury caused by any medical malpractice regulated under principles of public law, according to Article 13 of the Code of Administrative Procedure (IYUK), the injured party must apply to the relevant administration for compensation for the damage caused by the service administration within one year and in any case five years after learning of the damage or consequential damage. The administration decides the application within 60 days or implicitly rejects the application. Within 60 days following the date of notification of the decision or the end of the $30^{\text {th }}$ day, the IYUK should file a full judicial action against the administration in accordance with Article 36 of the competent administrative court in accordance with Article 2/1-b. The administration is obliged to report the full jurisdiction to the responsible physicians.

In the event that compensation is awarded as a result of the case, the administration may recourse to the resident physician and the supervising physician within the scope of Article 73 of TBK within two years and in any case within ten years.

\section{DISCUSSION}

The liability of physicians in terms of medical malpractice itself is undisputed. As an exception to this responsibility, in accordance with the circular, the educator, chief resident, and specialist physician supervising over the resident physician are liable for the actions performed 
by the resident physician. Although criminal liability of the supervisor may be indirect, due to privity of crime and punishment, it is still present due to misconduct of duty. On the other hand, legal responsibility of the resident physician's medical practices is imposed on the supervising physician as understood from the circular's obligation to "strictly supervise the correct execution of the application", although the supervising physician does not execute the practice, he/she is held responsible for the result of this medical practice and the errors caused by the application together with the resident physician. In our opinion, this liability can be based on comparable provisions of TBK Article 66 as the liability of the employer for the actions caused by fault of the employee. This liability of the supervising physician is not an absolute one, but of duty of care. In accordance to full litigation, filed and concluded in accordance with procedure, due to compensation paid by the administration to the injured party, the administration's legal recourse to the extent of the defects of the resident physician and supervisor, the supervising physician can be relieved of the responsibility by proving that he/ she has fulfilled the duty of care and that there is no proper causal link between the defect and his/her action.

* Supreme Court (Yargitay) HGK 2014/13-566 E., 2015/1339 K. and 13/05/2015 T.; Supreme Court (Yargitay) HGK 2013/4- 1533 E., 2015/1099 K. and 27/03/2015 T.; $10^{\text {th }}$ Chambers $1988 / 1042$ E., 1989/857 K., 20.04.1989.

** Except for the preparatory classes, those who have completed ten-semester undergraduate education are considered to possess master's degree.

*** "Criminal responsibility is personal. No one can be held responsible for the action of anyone else."

\section{Related legislation}

- Code of Administrative Procedure
- Regulations for Graduate Education

- T.C. Ministry of Health General Directorate of Health Services Circular dated 28/09/2012 and numbered B.10.0.SHG.0.18.00.00-252.99-

- Medical Deontology Regulation

- Regulation on Specialist Training in Medicine and Dentistry

- Turkish Code of Obligations

- Turkish Penal Code

- Higher Education Law

\section{Declaration of conflicting interests}

The author declared no conflicts of interest with respect to the authorship and/or publication of this article.

\section{Funding}

The author received no financial support for the research and/or authorship of this article.

\section{REFERENCES}

1. Ünder EY. Asistan Hekimlerin Hukuki Sorumluluğu. İstanbul Barosu Sağlık Hukuku Merkezi-Sağlık Hukuku Makaleleri. 1. Baskı. İstanbul: İstanbul Barosu Yayınları; 2012.

2. Yargitay Hukuk Genel Kurulu (HGK) 2012/4-729 Esas, 2013/163 Karar, 30/01/2013 tarihi. Erişim linki: https://www.kazanci.com.tr [Erişim tarihi: 24.05.2019]

3. Güleç Uçakhan S. Maddi Tazminat Esasları ve Hesaplanması. 8. Baskı. Ankara: Seçkin Yayınları; 2017.

4. Yenerer Çakmut Ö. Tıbbi Müdahaleye Rızanın Ceza Hukuku Açısından İncelenmesi. İstanbul Barosu Sağlık Hukuku Merkezi-Sağlık Hukuku Makaleleri. 1. Baskı. İstanbul; 2003.

5. Hakeri H. Tıp Hukuku. 16. Baskı. Ankara: Seçkin Yayınlar1; 2019.

6. Polat O, Pakiş I. Tıbbi Uygulama Hatalarında Hekim Sorumluluğu. Acıbadem Üniversitesi Sağlık Bilimleri Dergisi 2011;2:119-25.

7. Türk Tabipler Birliği, Asistan Hekimin Hakları Var! Talep Ediyoruz: Nitelikli Uzmanlık Eğitimi" beyannamesi, Erişim linki: http://www.ttb.org. tr/kutuphane/14mart_asistan.pdf (Erişim tarihi: 24.02.2019] 